\title{
PELATIHAN PEMBUATAN SARANA UPAKARA PABERSIHAN DALAM PENGABDIAN MASYARAKAT PINANDITA SANGGRAHA NUSANTARA KOORDINATOR WILAYAH NUSA TENGGARA BARAT
}

\author{
I Made Ardika Yasa'), Ni Komang Wiasti") \\ 1)Program Studi PG-PAUD, Jurusan Dharma Acarya, IAHN Gde Pudja Mataram, Mataram, NTB, Indonesia \\ Corresponding author :I Made Ardika Yasa \\ E-mail :kpjm.ardika@gmail.com
}

Diterima 03 April 2021, Direvisi 06 April 2021, Disetujui 07 April 2021

\begin{abstract}
ABSTRAK
Agama Hindu memiliki aneka budaya yang patut dilestarikan, dan dikembangkan keberadaannnya demi ajeg dan kuatnya budaya tersebut seperti misalnya dalam pembuatan sarana upacara upakara yang tujuannya sebagai sarana persembahan yang tulus ikhlas kehadapan Ida Sanghyang Widhi Wasa sebagai bentuk sradha bhakti memantapkan diri. Dalam sloka Bhagawadgita IX.26 menyatakan bahwa "Patrram Puspham Phalam Toyam, Yo Baktya Prayacchati, Tad Aham Bhakya Upahrtam, Asname prayatat manah" artinya Siapapun yang dengan kesujudan mempersembahkan padaku, sehelai daun sekuntum bunga, sebiji buah-buahan, seteguk air aku terima sebagai persembahan bagi orang yang berhati suci. Memaknai arti dari sloka tersebut diperlukan suatu upaya untuk memberikan pemahaman kepada masyarakat Hindu agar memiliki pemahaman konsep sehingga tidak terjadi salah tafsir dalam mengaplikasikan dalam tatanan kehidupan bermasyarakat. Hal tersebut yang berperan penting dalam memberikan informasi terkait sarana upakara yakni para rohaniwan yang telah di Dwijati dan Ekajati, Sulinggih dan Pinandita. Pinandita Sanggraha Nusantara Koordinator Wilayah Nusa Tenggara Barat sebagai organisasi kerohaniwan memiliki pogram kerja yang mengarah pada peningkatan sumber daya spiritual umat Hindu. Tujuan dilaksanakannya kegiatan "Pelatihan Pembuatan Upakara Pabersihan" ini ialah untuk mengoptimalkan peran dan tugas secara sosial, agar kreativitas seni metetuasan dapat dibangkitkan dan dilestarikan sebagai warisan budaya leluhur yang sangat mulia.
\end{abstract}

Kata kunci: pelatihan; sarana upakara; pabersihan.

\begin{abstract}
Hinduism has a variety of cultures that should be preserved and developed its existence for the sake of ajeg and the strength of the culture, such as in the making of upakara ceremony facilities whose purpose as a means of offering sincerely before Ida Sanghyang Widhi Wasa as a form of sraddha bhakti established itself. In the sloka Bhagawadgita IX.26 states that " Patrram Puspham Phalam Toyam, Yo Baktya Prayacchati, Tad Aham Bhakya Upahrtam, Asname prayatat manah" means Anyone who intended to present to me, a leaf of a flower, a piece of fruit, a sip of water I received as an offering to a saintly person. Interpreting the meaning of the sloka is necessary to understand the Hindu community understand the concept so that there is no misinterpretation in applying it in public life. It plays an important role in providing information related to upakara facilities, namely the clergy who have been in Dwijati and Ekajati, Sulinggih and Pinandita. Pinandita Sanggraha Nusantara, Coordinator of West Nusa Tenggara Region as a spiritual organization, has a working program that leads to the increase of spiritual resources of Hindus. The purpose of the activity "Training on Making Upakara Pabersihan" is to optimize the role and tasks socially so that the creativity of the art of metetuasan can be raised and preserved as a very noble ancestral cultural heritage. .
\end{abstract}

Keywords: training; upakara facilities; cleaning.

\section{PENDAHULUAN}

Upacara merupakan salah satu wahana yang sangat besar peran, fungsi dan pengaruhnya dalam menanamkan nilai-nilai dasar ajaran agama Hindu sehingga dapat meningkatkan sradha dan Bhakti antara pemuja dengan yang dipuja (Ardika Yasa, 2020). Kegiatan upacara tidak terlepas dari sarana upakara sebab umat Hindu khususnya umat Hindu yang berdomisili di Bali menempatkan sarana upakara selain sebagai media untuk melakukan komunikasi horizontal guna mencurahkan ekspresi wujud rasa puji syukur dan terimakasih kepada sang pencipta, sarana upakara juga dipandang sebagai media ritual yang memiliki makna simbol yang 
mengandung kekuatan magis sehingga untuk dapat terhubung dengan dunia gaib maka diperlukan sarana penunjang berupa upakara tersebut. Secara konseptual pula upakara sebagai sarana dalam berupacara juga didalamnya mengandung berbagai nilai-nilai susila khususnya etika dan sangat berperan penting dalam penguatan sradha dan bhakti umat Hindu (Gunada, 2020). Umat Hindu yang berdomisili di Lombok juga memiliki tradisi dan budaya yang memiliki kesamaan dengan tradisi dan budaya Hindu yang ada di Bali sebab seperti yang kita ketahui leluhur umat Hindu yang ada di Lombok sebagian besar berasal dari Bali.

Seiring dengan perkembangan jaman begitu pula dengan meningkatnya pemahaman dan daya nalar manusia untuk berpikir lebih kritis dan visioner hal itu tidak dapat dipungkiri akan membawa dampak perubahan terhadap perkembangan sarana Upakara keagamaan di Bali maupun di Lombok, walaupun sarana upakara keagamaan di Bali memiliki ciri khas tersendiri dan menjadi salah satu warisan dari leluhur mereka secara turun-temurun dari generasi ke generasi. Sehingga tradisi ini menjadi suatu budaya hidup manusia dalam berinteraksi sosial kemasyarakatan, berkomunikasi dengan Tuhan dan lingkungannya (Made et al., 2020). Menyikapi permasalahan tersebut di atas maka Pinandita Sanggraha Nusantara menganggap perlu untuk diadakan pelatihan pembuatan sarana upakara sehingga berinisiatif untuk mengadakan dan memfasilitasi kegiatan pelatihan pembuatan sarana upakara pabersihan dengan tujuan untuk melestarikan budaya Hindu serta menyatukan persepsi para peserta pelatihan yang nantinya mungkin akan menjadi srati banten tentang nilai-nilai filosofis, makna simbolis, etika metanding dan ragam tetuasan dalam pembuatan suatu sarana upakara

\section{METODE}

Pengabdian kepada masyarakat adalah salah satu kewajiban utama yang harus dilaksanakan oleh Pinandita Sanggraha Nusantara. Kegiatan Pengabdian kepada masyarakat kali ini dilaksanakan dalam bentuk Pelatihan pembuatan Sarana Upakara Pabersihan dalam rangka melestarikan Budaya Hindu yang berlandaskan pada ketulusan hati sehingga dapat memperkuat sradha dan bhakti kepada Ida Sang Hyang Widhi atau Tuhan yang Maha Esa.

Pengabdian masyarakat ini memilih lokasi di Pura Jagadnatha Mayura dengan dasar pertimbangan bahwa pura Jagatnatha mayura sangat representative untuk menunjang kelancaran, kenyamanan dan keamanan untuk mengadakan kegiatan tersebut karena selain sarana dan prasarananya yang sangat memadai, areal tempat pelaksanaan pelatihan dan areal tempat parkir yang sangat luas serta dekat dengan pusat kota selain itu pengelola pura dan taman mayura sangat mendukung adanya kegiatan yang tujuanya untuk kepentingan bersama menuju kearah positif terlebih untuk Umat Hindu sehinggga dengan demikian maka penyelenggara kegiatan tidak mengeluarkan biaya tambahan untuk sewa tempat ataupun biaya kebersihan. Seperti yang kita ketahui bahwa Setiap kegiatan tentunya memiliki jadwal sebagai acuan dalam pelaksanaan kegiatan begitu juga dengan pelatihan upakara sarana pabersihan ini memiliki jadwal seperti yang tertera pada Tabel 1. dibawah ini:

Tabel.1. Jadwal Pelaksanaan Kegiatan

Pelatihan Sarana Upakara Pabersihan

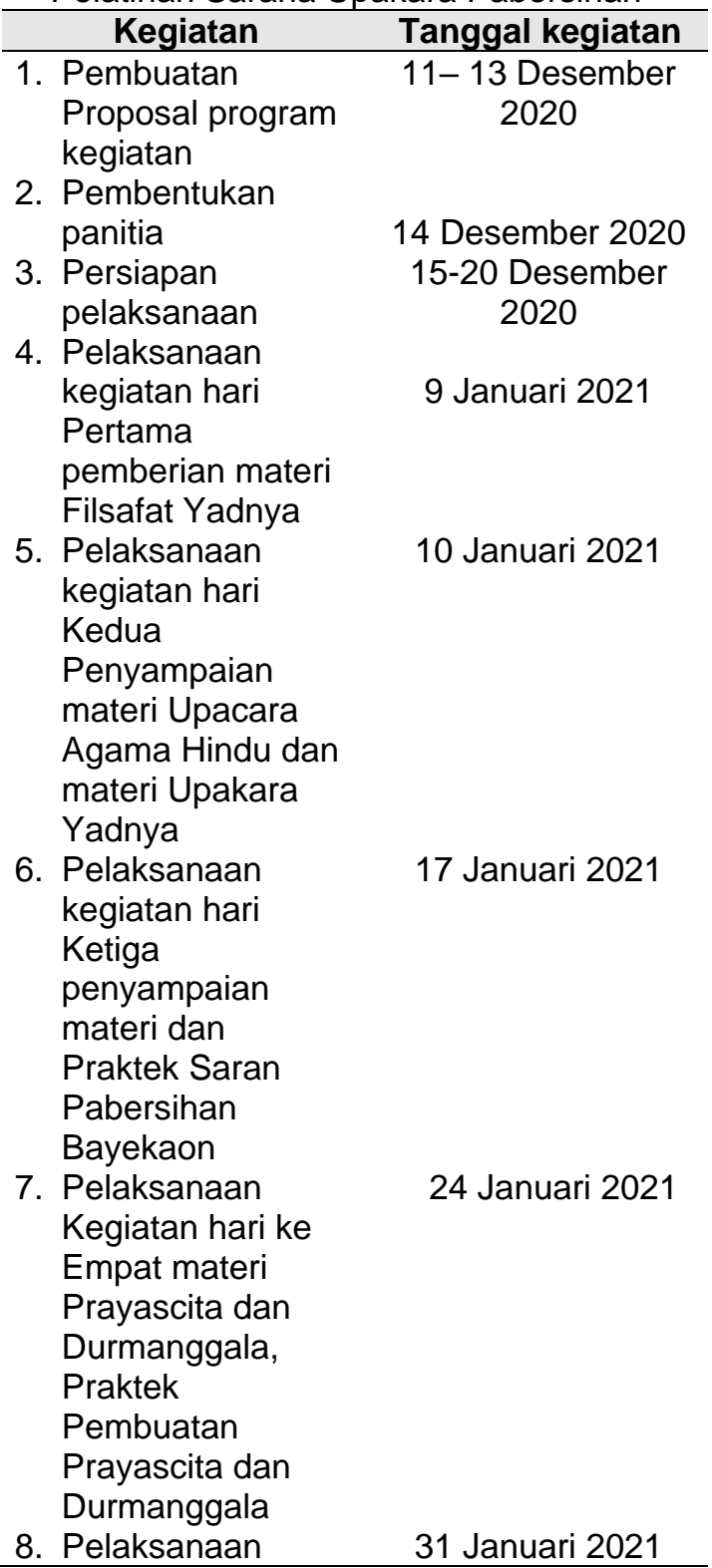




\begin{tabular}{|c|c|}
\hline $\begin{array}{l}\text { Kegiatan Hari Ke } \\
\text { Lima } \\
\text { penyampaian } \\
\text { materi dan praktek } \\
\text { etika metanding } \\
\text { 9. Monitoring, } \\
\text { Evaluasi dan } \\
\text { pelaporan } \\
\text { kegiatan }\end{array}$ & 1-5 Februari 2021 \\
\hline
\end{tabular}

Kegiatan pelatihan sarana upakara pabersihan ini didalam pelaksanaanya melalui beberapa tahapan yaitu;

\section{Tahap Pra Kegiatan}

Sebelum melaksanakan kegiatan Pelatihan panitia pelaksana melakukan koordinasi dan konsultasi untuk menggali informasi kepada seluruh anggota pengurus Pinandita Sanggraha Nusantara Koordinator Wilayah Nusa Tenggara Barat selaku penyelenggara dan koordinasi dengan PHDI maupun Organisasi Masyarakat lain agar mendapatkan masukan terkait lokasi pelaksanaan kegiatan pelatihan setelah mendapat masukan maka disusun Proposal Kegiatan dan mengadakan rapat koordinasi untuk membentuk tim panitia pelaksana kegiatan dan disahkan dalam bentuk Surat Keputusan Ketua Pinandita Sanggraha Nusantara nomor: 20/SK.PAN/PSNNTB/XII/2020 tentang panitia pelatihan pembuatan sarana upakara Pinandita Sanggraha Nusantara koordinator wilayah Nusa Tenggara Barat.

Setelah melalui rapat dan koordinasi keseluruh organisasi masyarakat Hindu maka kegiatan ini diputuskan untuk dilaksanakan bertempat di Pura Jagatnata taman mayura dengan kesepakatan jumlah peserta maksimal 50 orang peserta sehingga dari 82 orang peserta 32 orang peserta tereliminasi dan akan diminta kesediaanya untuk mengikuti kegiatan pelatihan upakara pada kegiatan tahap berikutnya. Adapun peserta terdiri dari kalangan pinandita, mahasiswa IAHN Gde Pudja Mataram, Dosen dan kalangan masyarakat umum. Pada tahap ini rencana dan program persiapan perencanaan Pengabdian yang meliputi pembentukan panitia melalui rapat organisasi, usulan pengajuan judul ataupun tema kegiatan, melakukan pengumpulan, pengolahan, klarifikasi dan penyajian data lokasi pelatihan dalam rangka pengabdian masyarakat, penyusunan Surat Keputusan (SK), dan penyusunan RAB telah tuntas dilaksanakan.

\section{Tahap Kegiatan}

Merupakan tahap pelaksanaan rencana kegiatan dimana pada tahapan ini panitia pelaksana kegiatan menyiapkan sarana dan prasarana kegiatan baik dalam bentuk suratmeyurat, pemasangan spanduk, menyiapkan sarana konsumsi, menyebarkan undangan, menghubungi narasumber untuk koordinasi dan konsultasi terkait materi yang hendak disampaikan, menyiapkan dekorasi tempat pelaksanaan kegiatan sebagai wujud tindak lanjut realisasi dan pelaksanaan rencana kegiatan;

Pada awal kegiatan peserta pelatihan upakara melalui tahapan sakralisasi yaitu mengikuti acara penyucian diri dan mohon restu kepada tuhan dalam bentuk kegiatan upacara matur piuning dan Ngadegang Betara Tarpini agar beliau bersedia dan berkenan merestui peserta pelatihan upakara agar mudah mempelajari pembuatan saran upakara tersebut dan peserta pelatihan diberikan semacam pretest secara lisan untuk mengukur sejauh mana keterampilan, kemampuan dan pengetahuan dasar peserta pelatihan upakara sebelum peserta pelatihan upakara mendapatkan materi dalam bentuk Praktik, Ceramah, dan diskusi berdasarkan sesi tanya jawab pada saat kegiatan teori dan praktik. Dan pada akhir kegiatan peserta pelatihan upakara diberikan posttest untuk mengukur sejauh mana ketercapaian kegiatan proses pelatihan baik dari segi pengetahuan berdasarkan materi yang disampaikan oleh pelaksana kegiatan pelatihan maupun keterampilan peserta berdasarkan kegiatan praktek yang telah dipandu oleh panitia pelaksana pelatihan upakara. Dalam pelaksanaan kegiatan penyampaian materi narasumber menggunakan LCD proyektor dan alat praga dalam bentuk contoh jejaitan/tetuasan yang disiapkan oleh panitia pelaksana kegiatan dan dibantu secara partisipatif oleh peserta pelatihan upakara.

Karena sasaran utama dari kegiatan pengabdian ini adalah umat Hindu namun peserta kegiatan pelatihan pembuatan sarana upakara pabersihan ini mayoritas lanjut usia maka untuk meningkatkan semangat, motivasi, antusias peserta pelatihan upakara mengikuti proses pembelajaran maka narasumber haruslah paham dan menguasai tentang tehnik pendidikan untuk orang dewasa yang dikenal dengan andragogi dimana pelaksanaan kegiatan pelatihan narasumber dominan menggunakan metode diskusi dalam bentuk tanya jawab pemecahan terhadap suatu masalah, eksperimen dan praktik (Sunhaji, 1970). jadi agar peserta pelatihan upakara merasa semangat dan nyaman dalam 
mengikuti proses pembelajaran maka selain menata ruang agar terasa nyaman juga didalam kegiatan pembelajaran Pelaksana Kegiatan menciptakan situasi yang bersahabat dan tidak formal serta menggunakan metode yang bervariasi sehingga dalam proses belajar mengajar pada pelatihan upakara terjadi secara fleksibel.

\section{Tahap Monitoring Evaluasi}

Pada tahapan ketiga ini mengingat situasi dan kondisi Pandemi Covid-19 maka panitia pelaksana pengabdian masyarakat melaksanakan proses monitoring dengan menggunakan aplikasi zoom meeting yang sebelumnya peserta diberikan informasi jadwal pelaksanaan kegiatan dan link zoom meeting pada aplikasi Grup Whatsapp setelah itu panitia pelaksana kegiatan melakukan observasi dan mewawancarai peserta pelatihan secara lisan dengan sistem tanya jawab untuk memperoleh informasi sejauh mana keberhasilan kegiatan pelatihan ini baik dilihat dari perubahan segi keterampilan dan pengetahuan peserta setelah itu seluruh data dan informasi tersebut direduksi, dan dianalisis. Penggunaan model daring dalam proses evaluasi juga berkenaan sebagai salah satu usaha untuk ikut serta dalam pencegahan dan penyebaran virus covid-19 sehingga dalam prosesnya juga memperhatikan penerapan protokol kesehatan (Gunada \& Pramana, 2021).

\section{Tahap Pelaporan}

Siswa yang baik adalah siswa yang selalu mempelajari semua pengetahuan dan meningkatkan keterampilan serta turut serta berperan aktif dalam rangka merekonstruksi dan mengembangkan pengetahuan jadi begitu juga halnya dengan peserta pelatihan upakara ini dapat ditentukan bahwa mereka aktif ataupun tidak dalam kegiatan tersebut akan terlihat pada laporan kegiatan yang merupakan hasil suatu evaluasi dimana pada tahapan tersebut sebelumnya melalui tahap monitoring dan evaluasi (Bartin, 2018).

Pada tahap keempat ini hasil dari monitoring dan evaluasi tersebut dituangkan pada pelaporan pelaksanaan kegiatan pelatihan dimana pada tahapan ini laporan kegiatan disampaikan kepada Ketua Pinandita Sanggraha Nusantara Koordinator Wilayah Nusa Tenggara Barat setelah berakhirnya kegiatan Pelatihan untuk disahkan sebagai bahan pelaporan yang akan disampaikan kepada Pinandita Sanggraha Nusantara Pusat ataupun kelembaga tempat bekerja anggota panitia pelaksana pengabdian masyarakat yang telah memberikan surat tugas untuk ikut serta melaksanakan kegiatan pelatihan sarana upakara pabersihan ini.

\section{HASIL DAN PEMBAHASAN}

Berdasarkan hasil analisa terkait kegiatan Pelatihan sarana upakara pabersihan yang diadakan oleh Pinadita Sanggraha Nusantara yang dilaksanakan di pura Jagatnatha Mayura maka dapat dijelaskan sebagai berikut :

Bahwa setiap Kegiatan tentunya harus memiliki jadwal rencana kegiatan sebelum kegiatan tersebut diselenggarakan, agar terlaksana dengan sistematis dan berjalan lancar, dengan demikian maka kegiatan pelatihan sarana upakara pabersihan inipun dilaksanakan sesuai jadwal rencana kegiatan yaitu pada awal tahun 2021 tepatnya pada tanggal 09 Januari sesuai dengan jadwal pelaksanaan kegiatan pelatihan saran upakara Pabersihan yang telah ditentukan dan dilaksanakan yang tertera pada tabel 1.

Kegiatan pelatihan ini mendapat respon positif dari kalangan masyarakat hal itu ditunjukkan dengan banyaknya peminat yang ingin mengikuti kegiatan pelatihan upakara ini, pada hari pertama pembukaan registrasi pendaftaran calon peserta pelatihan terdapat 82 orang namun karena mengingat situasi pandemi Covid-19 dan kondisi lokasi tempat pelatihan yang hanya dapat mengakomodir peserta maksimal 60 orang maka jumlah peserta dibatasi dengan jumlah kuota sebanyak 50 orang peserta agar tetap ideal dan sesuai dengan protokol kesehatan dalam melakukan kegiatan di masa pandemi covid-19 ini. Dan didalam kegiatan pelatihan upakara ini peserta sangat antusias, serius menyimak dan interaktif dalam mengikuti pelatihan baik pada sesi penyampaian materi maupun praktik yang ditunjukan dengan adanya berbagai pertanyaan dari peserta pelatihan terkait materi yang disampaikan oleh narasumber sehingga kegiatan penyampaian materi maupun praktek menjadi sangat interaktif.

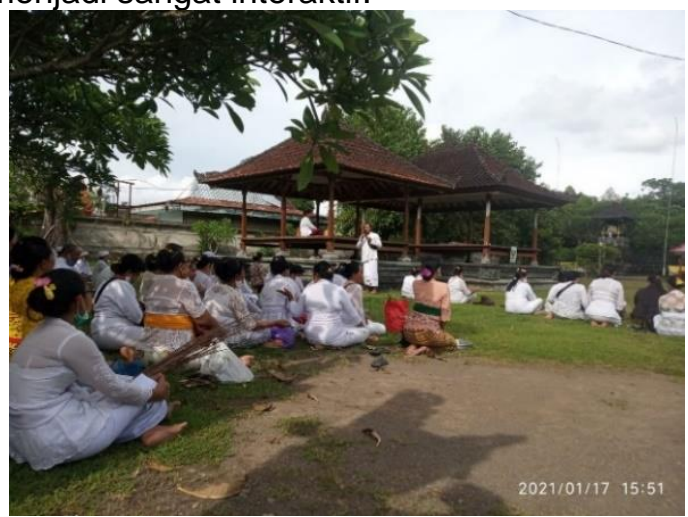

Gambar 1.Kegiatan Matur Piuning dan ngadegang Batara Tarpini ( Sumber: I Made Ardika Yasa) 


\section{Penyampaian Materi Filsafat Yadnya}

Yajna berasal dari kata Yaj

yang artinya "korban" dengan demikian yajna dapat diartikan korban suci yang dipersembahkan secara tulus dan ikhlas (Rai \& Pitriani, 2020). Seperti yang kita ketahui umat Hindu diisetiap melaksanakan kegiatan yajna tentunya menggunakan sarana upakara dengan demikian kita dapat berpikir bahwa tentunya saran upakara tersebut harusnya diperoleh dengan jalan darma dan masih sukla serta dijaga kesucianya karena sarana upakara tersebut akan dipersembahkan kepada Brahman atau Ida Sang Hyang Widhi.

Dengan demikian sarana upakara yang dibuat oleh umat Hindu tentunya memiliki syarat ketentuan dalam proses pembuatanya, sebab sarana upakara umat Hindu tidak hanya dilihat dari segi estetika saja namun simbol yang terkandung didalamnya yang mengharuskan si pembuat sarana upakara atau yang sering dikenal dengan srati banten untuk menghormati kesucianya tidaklah boleh membuat sarana upakara sembarangan harus menggunakan bahan sesuai ketentuan, pada saat pembuatanyapun harus menggunakan etika sehingga pada saat pelaksanaan upacara nilai kesakralan akan diperoleh.

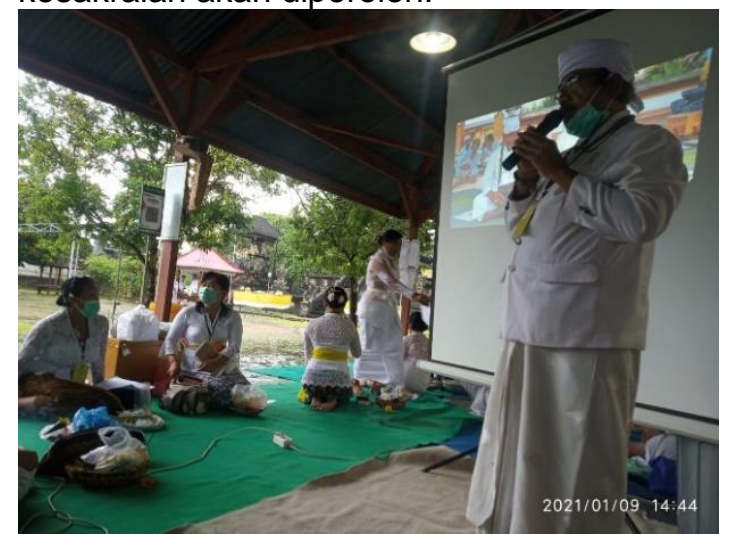

Gambar 2.Pemberian materi filsafat yadnya ( Sumber: I Made Ardika Yasa)

Bahan dasar pembuatan sarana tersebut ada pada lontar pelutaning yadnya. bahan-bahan upakara terdiri dari Mataya atau segala jenis tumbuhan, Maharya terdiri dari semua jenis binatang yang lahir dari 1 kali tahapan, Mantiga terdari dari bahan hewani yang mengalami proses lahir 2 kali seperti menjadi telur terlebih dahulu baru menjadi hewan. Sejarahnya agar apa yang ada seperti tumbuhan di muka bhumi dipersembahkan dengan menganut konsep cakra yadnya, Dalam Weda dinyatakan bahwa manusia hidup karena tumbuhan, tumbuhan karena hujan, hujan karena yadnya. Sarana tersebut dikelompokkan seperti ron, ental, busung (sifat kedewataan), slepan (sifat keraksasaan), dengan tumbuh-tumbuhan itu dijadikan suatu bahan dasar persembahan secara spiritual dimaknai bahwa tumbuhan tersebut akan mendapatkan peningkatan kualitas hidupnya di masa yang akan datang.

Ngerainin (ngaturangpakeling) mengadakan upacara inti tingkatan nista misalnya banten pejati ditambah sesayut menurut kemampuan (bisa pemangku yang nganteb) proses acara sangat sederhana dan simple, sedangkan kalau Odalan berasal dari kata wedal (lahir), artinya memperingati mulainya disucikan dan disakralkan areal pura, pelinggih tersebut dengan mulang pedagingan, melaspas. Bantennya bisa tingkatan (apajeg, atau menggunakan hitungan tumpeng ganjil $5,7,11$, ganjil memiliki makna samkya yang sangat penting dalam Hindu), Madya (asoroh, tumpeng 15/17) dan Utama (Adandanan tumpeng 27/33) dengan pemuput pedanda/sulinggih. Dengan dudonan upacara yang lebih banyak dan waktu yang agak lama sesuai kesepakatan misalnya ada upacara ngadegang (awal), Inti Puncak Piodalan, Nyineb (diakhir) Kesemua tingkatan tersebut memiliki tujuan dan fungsi yang sama. Ada pepatah jawa menyebutkan wangi abale agung alah dening dapetan sadulang, dapetan sadulang alah dening puja mantra, puja mantra alah dening manah suci nirmala. Makna filosofi antara ngerainin dan ngodalin adalah sama memuja kebesaran Ida Sang Hyang Widhi dan prabhawanya, leluhur, bethara-bethari yang telah memberikan waranugrahanya kepada semua ciptaannya

\section{Penyampaian Materi Upacara Agama Hindu dan materi Upakara Yadnya}

Upacara agama Hindu tidak terlepas dari peran sarana upakara sebab kedua hal tersebut sangat berkaitan bagaikan dua sisi mata uang yang tidak dapat dipisahkan jikapun dipisahkan maka tidak akan memiliki nilai sehingga kedua hal tersebut haruslah sinergi agar pelaksanaan yajna dapat berjalan dengan lancar.

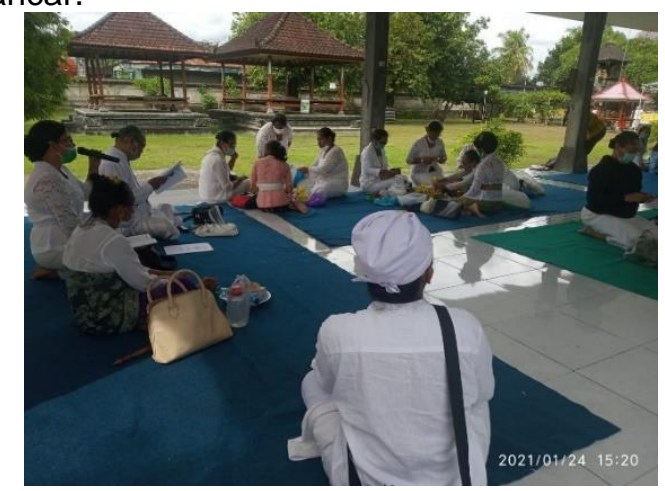

Gambar 3.Pemberian materi Upacara Agama Hindu dan Materi Upakara Yadnya ( Sumber: I Made Ardika Yasa) 
Pelaksanaan upacara adat keagamaan bagi umat Hindu yang khususnya berdomisili di Bali memiliki keanekaragaman baik sarana upakara ataupun sistematika urutan proses pelaksanaannya hal itu disebabkan oleh keberagaman pemahaman sudut pandang ataupun tafsir ketuhanan dalam wujud komunikasi horizontal sehingga dalam memaknai suatu simbol keagamaan terjadi multi tafsir sehingga pada konteks ini terkait dengan sarana bebantenan baik unsur pembentuknya ataupun makna filosofi bentuknya menjadi beraneka ragam (Ardika Yasa, 2020).

Umat Hindu khususnya di Bali melaksanakan berbagai macam Upacara Agama dengan berbagai jenis variasi sarana upakara sebab umat Hindu di bali sebagian besar menganut ajaran siwa sidhanta. Seperti yang kita Ketahui bahwa agama Hindu memiliki lima keyakinan yang dikenal dengan istilah Panca Sradha, dan terlahir menjadi Hindu karena ajaran Tri Rna (3 hutang) sesuai dalam Bhagawadgita. III.10, adanya Ajaran Catur Marga Yoga (4 Jalan menuju Tuhan) dan agama Hindu mengembangkan ajaran kasih sayang pada semua ciptaannya. Untuk meningkatkan kualitas dirinya sebagai Hindu maka diadakanlah pelaksanaan Upacara agama yang disebut dengan Panca Yadnya sesuai dengan tujuan agama Hindu mencapai moksa. Upacara ritual hanya salah satu bagian yadnya, yang merupakan warisan tradisi leluhur yang adiluhung karena dapat mengembangkan budaya seni (estetika) metetuasan. Hindu dikagumi dikenal karena bentuk seni upacaranya, sehingga perlu dilestarikan (Surayin, 2002). Fungsi upacara sebagai ungkapan rasa syukur dan terimakasih terhadap kesehatan, rejeki, dan kebahagiaan semua mahkluk yang diciptakan oleh Sanghyang Widhi Wasa, serta sebagai penuntun spiritual rohani umat Hindu.

Upacara yang dilaksanakan tidak harus menghabiskan biaya besar. Dalam ajaran kitab suci agama Hindu sudah jelas disampaikan bahwa dalam pelaksanaan yadnya ada tingkatan upacara yaitu, nista, madya, utama. Tergantung pilihan, sesuai kemampuan secara ekonomi umat Hindu dalam melaksanakan upacara. Ketiga tingkatan tersebut kualitasnya sama yang terpenting keikhlasan. Agama Hindu agama Tradisi, warisan leluhur. Dalam melanjutkan ajaran leluhur perlu pemahaman yang jelas tentang teori-teori beragama dan berupacara, agar tidak menjadi beban yang menderitakan. Ajaran Upacara Panca Yadnya yang kita laksanakan tujuannya untuk keseimbangan dan keharmonisan lingkungan, sesuai konsep Tri Hita Karana (Arta Jaya, 2019).
Pelaksanaan Upacara yadnya bagi umat Hindu secara tidak langsung akan berdampak pada perputaran ekonomi umat, subsidi silang, terjadi kerjasamanya yang baik antara tukang banten, dengan sang yajamana (mahkluk sosial) begitu sebaliknya. Dalam hal lain tidak hanya sebatas upacara yang merupakan yadnya. Misalnya bhuta yadnya perbuatan cinta lingkungan, merawat dan memelihara tanaman, membuang sampah pada tempatnya, dan pitra yadnya misalnya merawat dan membesarkan anak, memenuhi semua kebutuhan yang diperlukan penting untuk kemajuan dirinya, dan Rsi Yadnya misalnya memberikan suguhan (rsi Bhojana), dana punia kepada Rohaniwan, dan masih banyak contoh perbuatan yang tergolong yadnya lain. Sesungguhnya setiap hari dalam kehidupan kita sudah melaksanakan yadnya/ persembahan.

Sarana Upakara dalam umat Hindu Bali dikenal dengan istilah Banten dan Keanekaragaman sarana upakara dalam berbagai kegiatan upacara tersebut disesuaikan dengan desa, kala, patra sebab Semua banten tersebut hanya variasi, ragam jenis misalnya banten Byakala di masing masing daerah seperti bali, Lombok ataupun daerah lainnya walaupun memang dalam unsurnya ada sedikit perbedaan namun esensi dan makna penggunaannya sama, yaitu untuk penyucian alam bhur (bawah). Banten bayekaon dipergunakan sebagai banten pembersihan areal lingkungan seperti di areal pelinggih atau pura diayab kebawah, pada upacara manusia yadnya (pawiwahan, otonan, hari raya penampahan galungan) dan pada upacara mecaru. Anak yang belum tanggal giginya tidak mebyakala karena masih tergolong sifat kedewataan (Surayin \& Ida Ayu, 2002).

\section{Penyampaian materi dan Praktek Sarana Pabersihan Bayekaon}

Pada kesempatan ini panitia yang menjadi narasumber menyampaikan materi tentang Bayekaon tersebut dengan menggunakan sarana alat peraga dan menyampaikan secara detail satu persatu bagian dari unsur penyusun banten bayekaon dan menjelaskan makna arti symbol dari unsur bahan penyusun banten tersebut. Adapun kegiatan penyampaian materi dan praktek tersebut dapat terlihat pada Gambar.4 


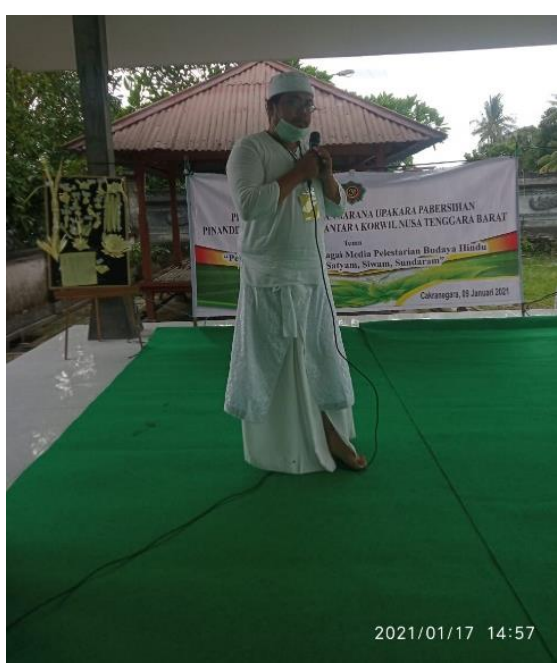

Gambar 4.Pemberian materi dan Praktek Sarana Pabersihan Bayekaon ( Sumber: I Made Ardika Yasa)

Dalam pembuatan sarana upakara Bayekaon hendaknya menggunakan busung Hijau atau Slepan sebab pada Pelutuk atau pakem bebantenan agama Hindu, sarana upakara memiliki sifat asuri sampat (Keraksasaan) dan daiwi sampad (kedewataan). Oleh karena sifat persembahan sebagai upakara penyucian (kotoran), sehingga menetralisir sifat dan hal buruk sehingga didalam pembuatan sarana upakara bayekaon ada tetuasan menggunakan slepan atau janur hijau.

Sarana upakara yang terbuat dari bahan janur warna kuning memiliki makna simbol sifat kedewataan. Kemudian Karena saat ini kita menghargai perkembangan teknologi, jaman modern, mengenal simple dan praktis, bisa disimpan dalam waktu yang lebih lama, sehingga kalau ibu-ibu yang sibuk bekerja, bisa membuat jauh-jauh hari mempersiapkan jaitan untuk hari raya. Akan tetapi terkadang umat Hindu ada yang mejejahitan dengan menggunakan janur Sulawesi atau yang dikenal dengan busung ibung merasa sarananya kurang segar, kemudian variasi reringgitannya tidak bisa terlalu banyak, ada kandungan unsur kimianya, sehingga jarang yang menggunakan busung ibung tersebut, mungkin kurang indah dari aspek estetika, namun semua itu kembali lagi ke individu. Namun hendaknya yang paling utama sebelum mebuat sarana upakara tersebut ialah srati banten atau sang pembuat sarana upakara harusnya menjaga kesucian diri ataupun bahan sarana terlebih dahulu, dengan pikiran tenang, hati yang tulus, berpakaian yang sopan/pantas dan tidak lupa untuk melatih sadhana spiritual sebagai umat Hindu baiknya setiap mengawali pekerjaan apapun hendaknya berdoa terlebih dahulu, adapun doa memulai pekerjaan yang dapat di lantunkan yaitu: Om Awighnam astu namo sidham yang artinya semoga pekerjaan hamba berhasil tanpa halangan atau dengan ditambah mantra om Prano Dewi saraswati, wajebhir wajiniwati dhinam anwinyawantu dimana doa ini di khususkan untuk memohon inspirasi agar didalam melaksanakan kegiatan dapat menimbulkan ide-ide cemerlang yang dapat mendukung kesuksesan pelaksanaan kegiatan. Sarana upakara merupakan sarana suci yang dapat menentukan kesakralan suatu upacara yang akan dipersembahkan kepada Brahman atau Tuhan yang maha ESA, begitu juga dengan sarana upakara bayekaon ini terdiri dari dua jenis berdasarkan bahan penyusun sarana tersebut ada yang pakai telur dan ada yang tidak menggunakan telur. Jika ada yang tidak menggunakan telur berarti bayakaon tersebut digunakan untuk upacara dewa yadnya karena proses ngaturangnya hanya diayab saja. Dan bila terkandung unsur telur ayam berarti memiliki simbol sifat rajas. Banten byakaon sifatnya penyucian agar sifat rajas yang ada pada diri seseorang dapat dinetralisir menjadi sifat satwam yang dominan dengan kebajikan (Arwati, 2003)

\section{Penyampaian materi dan Praktek Pembuatan Prayascita dan Durmanggala \\ Didalam pelaksanaan upacara yang} berkaitan dengan upakara Pabersihan atau pangresikan umat Hindu Bali ataupun Lombok mengenal tiga jenis banten yaitu Bayakala, Prayascita dan Durmanggala walaupun keduanya sama-sama merupakan banten pabersihan namun memiliki unsur bahan penyusunnya berbeda sehingga penempatan saat penggunaannya pada proses upacarapun berbeda walau dalam satu rangkaian kegiatan prosesi ritual. Didalam proses ritual Ketiga banten tersebut merupakan banten penyucian alam bhur (byakala) dengan simbol Brahma warna merah lambing Perbuatan, Bhuwah (Durmenggala) lambang Perkataan dengan simbol Wisnu, dan Swah ( Prayascita) Simbol Siwa lambang Pikiran. Byakala artinya penetralisir sifat-sifat prilaku yang buruk yang dilambangkan bhuta kala, Durmenggala artinya dur artinya menghilangkan, menggala artinya unek-unek, Durmenggala merupakan sarana banten yang fungsinya untuk menghilangkan unek-unek, perasaan yang tidak baik, yang berasal dari dalam diri maupun dari luar diri (ekternal) seperti prawesa (kemasukan binatang didalam rumah) pelinggih tertimpa pohon, bencana alam, melaspas bangunan dan prayascita berasal dari kata prayas artinya bahagia dan cita artinya (bahagia). Prayascita adalah banten yang berfungsi untuk 
menyucikan pikiran agar bahagia (bhuwana alit), bhuwana agung menyucikan areal pelinggih bagian atas (ayab keatas) simbol Siwa.

Prayascita merupakan salah satu sarana upakara yang berperan penting didalam suatu kegiatan upacara, sehingga banten Prayascita hampir selalu digunakan pada saat pelaksanaan yajnya dan tersusun dari beberapa komponen membentuk satu kesatuan untuk mewujudkan fungsi utamanya sebagai sarana upakara penyucian. Selain sebagai sarana penyucian fungsi Banten Prayascita juga sebagai media pemusatan pikiran, korban suci dan sarana pendidikan. Dalam proses pembuatan Banten Prayascita ditemukan nilai seni dan budaya dengan menciptakan jejahitan dan reringgitan yang indah, menggambarkan simbol para dewa yang mencermikan suatu keindahan yang sangat tinggi. Didalam proses pembuatan banten Prayascita hendaknya didasari atas kesucian diri baik lahir maupun batin serta dengan rasa hati yang tulus dan ikhlas sehingga tercipta kesucian pikiran, keheningan perasaan untuk meningkatkan sradha dan bakti umat kehadapan Ida Hyang Widhi Wasa. Setiap unsur penyusun didalam banten prayascita memiliki fungsi dan makna secara nilai filosofi mampu menjaga keseimbangan, keselarasan, keharmonisan antara manusia dengan Ida Hyang Widhi Wasa beserta manifestasinya (Sukiani, 2019).

Durmanggala adalah salah satu dari banten pabersihan yang digunakan untuk menyucikan segala hal yang membawa dampak buruk pada lingkungan tempat tinggal dalam arti mengembalikan keseimbangan, keharmonisan dan menebarkan virbasi positif pada rumah atau tempat tinggal agar tidak menjadi angker atau yang sering dikenal dengan sebutan istilah karang panas (Humanis et al., 2016). Rumah ataupun tempat hunian hendaknya sebelum di tempati terlebih dahulu di Ruat yang dimana umat Hindu dikenal dengan istilah melaspas, hal itu bertujuan untuk menghancurkan hal-hal yang menjadi pertanda buruk ataupun hal yang dapat membawa dampak negative sehingga dapat menebarkan aura positif agar keluarga yang tinggal dihunian tersebut merasa nyaman, tenteram, terhindar dari pertikaian ataupun percekcokan sehingga dapat hidup dengan tenang, harmonis serta hidup rukun berdampingan dengan tetangganya. Jika disimpulkan bahwa banten byakala, durmenggala dan prayascita merupakan simbol dewa Tri Murti, yaitu Brahma, Wisnu, dan Siwa, simbul penyucian Tri Kaya Parisudha tubuh/angga, Pikiran (prayascita), Perkataan (durmenggala) dan Perbuatan (Byakala). Sebagai catatan bahwa banten tersebut dibuat jika membuat banten ayaban tumpeng 9 ke atas atau 7 dulang merujuk pada dresta Lombok, jika dibawah itu cukup menggunakan penglukatan suci sukla, kekobok atau nirmala gening dan semua itu kembali kepada tingkatan Jnana manusia yang menempati suatu daerah yang menyumbangkan buah dari hasil ekspresi pemikirannya sehingga menjadi loka dresta sehingga masing-masing desa, kala, patra memiliki kesepakatan dalam menyusun ketentuan suatu sarana upakara yang menjadi tradisi dan budaya local genius masing-masing wilayah sehingga dapat kita jumpai ragam bentuk tetuasan, dan jenis banten (Sudana,2001).

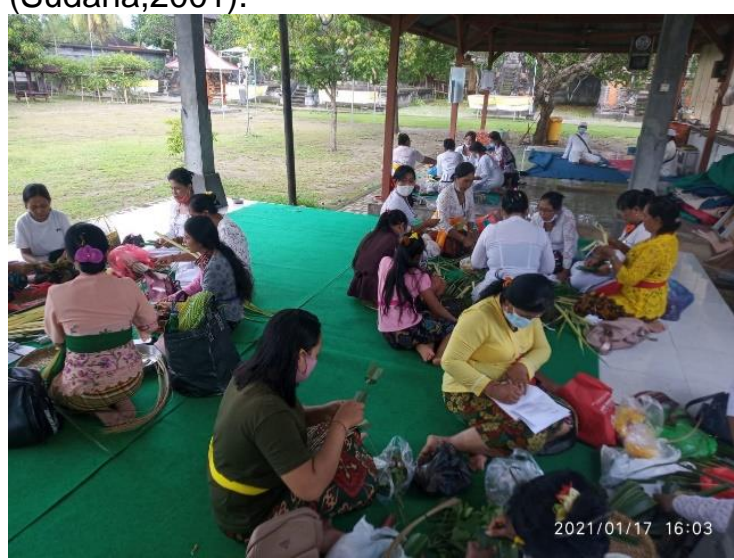

Gambar 5. Praktek pembuatan prayascita dan durmanggala ( Sumber: I Made Ardika Yasa)

\section{Penyampaian materi dan praktek etika metanding}

Metanding merupakan salah satu bagian penting dalam suatu proses pembuatan sarana upakara yajna sebab jika salah dalam metanding maka unsur bahan penyusun sarana upakara tersebut menjadi sia-sia dan tidak dapat disebut dengan banten.

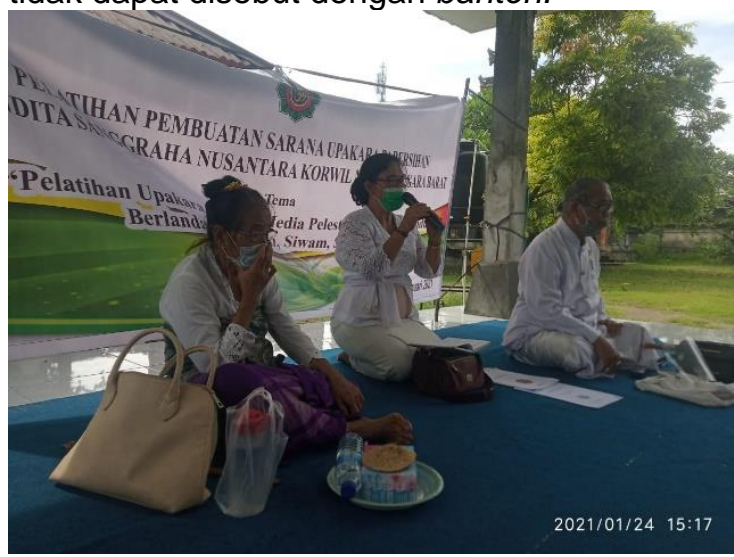

Gambar 6.Pemberian Materi terkait materi dan praktek etika metanding ( Sumber: I Made Ardika Yasa) 
Mengingat begitu pentingnya metanding dalam suatu proses pembuatan sarana upakara maka seorang srati banten harusnya mengetahui etika dalam metanding. Seperti yang disampaikan dalam lontar yadnya prakerti yaitu Sehananing bebanten pinaka ragantatuwi. pinaka warna rupaning lda Bhatara pinaka Andha Buwana. Yang artinya: Semua banten lambang diri kita (manusia), lambang kemahakuasaan Tuhan, lambang alam semesta. Bunga lambang kesucian dan ketulusan melakukan yadnya. Reringgitan dan tatuwasan (ukir ukiran pada banten) lambang kesungguhan pikiran melakukan yadnya. Raka raka (buah dan berbagai jajan pelengkap banten) lambang para ilmuwan sorga. Jadi selama sarana upakara atau banten itu di buat secara sungguh sungguh dengan hati yang penuh rasa tulus dan ikhlas maka sarana upakara tersebut akan menjadi persembahan utama yang akan diterima oleh Ida Sang Hyang Widhi Wasa (Asmoro et al., 2020).

\section{Monitoring, Evaluasi dan Pelaporan Kegiatan Pelatihan Sarana Upakara Pabersihan}

Keberhasilan suatu kegiatan dapat dilihat dari hasil evaluasi kegiatan dimana seperti yang kita ketahui setiap kegiatan memerlukan evaluasi untuk mengetahui sejauh mana ketercapaian tujuan dari kegiatan tersebut sebab Evaluasi merupakan salah satu tahap akhir dari proses suatu kegiatan sebab evaluasi merupakan usaha untuk mengidentifikasi, menganalisis, mengukur sejauh mana tingkat keberhasilan suatu kegiatan sesuai dengan aturan, prosedur yang telah ditentukan, hasil dari suatu evaluasi dituangkan dalam bentuk kesimpulan ataupun nilai yang ditulis pada suatu laporan hasil kegiatan. Penilaian suatu keberhasilan program pelatihan baik dalam bentuk teori maupun praktek tidak cukup hanya berdasarkan pada indikator penilaian hasil belajar peserta pelatihan, namun juga perlu menjangkau aspek desain program dan penerapan hasil pelatihan tersebut pada lingkungan sekitar ia tinggal (Rifandi, 2013).

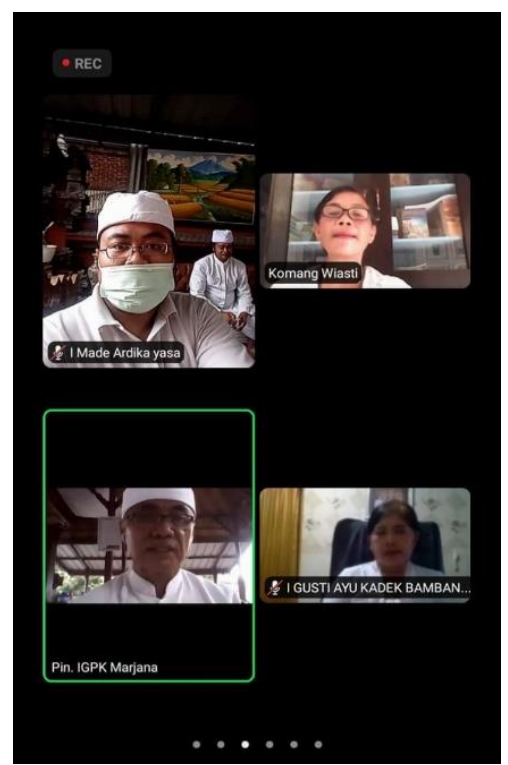

Gambar 7. Monitoring, Evaluasi Sekaligus penutupan kegiatan Pelatihan Upakara Via Aplikasi Zoom Meeting ( Sumber: I Made Ardika Yasa)

Berdasarkan hasil interaksi dan komunikasi secara daring dengan peserta pelatihan Upakara maka kegiatan pengabdian mandiri ini dapat dinyatakan telah berjalan sesuai dengan jadwal dan rencana pelaksanaan yang telah ditentukan.

Proses pembelajaran dalam kegiatan pelatihan meliputi penyampaian materi dan pendampingan praktek merupakan suatu kegiatan yang bernilai edukatif, dimana nilai edukatif tersebut tentunya terdapat feedback dari peserta pelatihan atas stimulus dalam bentuk informasi ilmu dan keterampilan yang telah ditransfer oleh panitia pelaksana kegiatan selaku narasumber sehingga tejadi interaksi antara peserta pelatihan dan instruktur yang menyebabkan terjalinnya komunikasi interaktif, sehingga komunikasi tersebut dapat terlaksana dengan sukses tanpa adanya distorsi yang berarti, dimana distorsi itu dapat mempengaruhi komunikasi sehingga dapat mengganggu kelancaran dalam proses pembelajaran dalam kegiatan pelatihan pembuatan sarana upakara pabersihan yang diselenggarakan oleh Pinandita Sanggraha Nusantara Koordinator Wilayah Nusa Tenggara Barat (Susanthi, 2021).

Tidak dapat dipungkiri bahwa didalam setiap pelaksanaan suatu kegiatan tentunya terdapat kendala begitu juga dengan kegiatan pelatihan upakara sarana pabersihan ini didalam pelaksanaanya terdapat beberapa hal yang menjadi kendala diantaranya 1) waktu pelaksanaan yang sangat singkat sehingga proses pelatihan menjadi kurang maksimal, 2) situasi pandemi ini membuat para peserta menjadi sedikit hawatir untuk melaksanakan 
kegiatan secara luring dan harus tetap taat mengikuti Protokol kesehatan yang dimana mereka sebelum masuk harus cuci tangan terlebih dahulu, mengatur jarak mereka duduk walau dalam satu kelompok, peserta pelatihan upakara harus siap sedia membawa handsanitaizer secara pribadi dan tetap menggunakan masker selama kegiatan berlangsung, 3. Karena tempat pelaksanaan kegiatan Pelatihan Pembuatan Sarana Upakara Pabersihan di areal utama pura maka ada beberapa peserta yang cuntaka sehingga berhalangan untuk hadir mengikuti kegiatan pelatihan, 4. Karena sebagian besar peserta pelatihan upakara merupakan pinandita sehingga memiliki rutinitas tingkat kesibukan yang tinggi pada hari-hari tertentu yang bertepatan dengan hari raya ataupun hari suci sehingga lebih mengutamakan melaksanakan tugas pokoknya sebagai pendamping ataupun bahkan sebagai manggala upacara sehingga berhalangan untuk hadir mengikuti kegiatan secara maksimal.

Dibalik berbagai kendala tersebut diatas terdapat keberhasilan didalam pelaksanaan kegiatan pelatihan sarana upakara pabersihan tersebut, diantaranya; 1) Sebagian besar peserta pelatihan upakara bertambah wawasanya dan memahami hakekat, makna simbolis sarana upakara pabersihan yang ditunjukan pada saat diskusi tanya jawab secara interaktif pada kegiatan penyampaian materi, 2). Seluruh Peserta bertambah keterampilannya dalam membuat sarana upakara Pabersihan dimana hal itu di tunjukkan pada saat kegiatan praktik mereka dapat membuat sendiri tetuasan ataupun dapat membuat banten secara berkelompok sesuai dengan instruksi pada penugasan tiap kali pertemuan sesi praktik. 3) Peserta pelatihan upakara memiliki pemahaman secara filosofis dan etika dalam proses metanding, walaupun terlihat sepele namun hal itu sangat penting dalam menjaga kesakralan sarana upakara dan hal itu dibuktikan dengan sikap mereka yang sopan, sabar, tenang, santun dalam metetuasan dan menggunakan sarana prasarana sukla serta memakai pakaian yang sopan dan pantas. 4. Meningkatnya pemahaman spiritual peserta pelatihan upakara dengan ditunjukkan pada sikap dan kebiasaan mereka yang terlebih dahulu berdoa sebelum memulai membuat sarana upakara pabersihan dan seusai membuats arana tersebut mereka menghaturkannya sebagai wujud bhakti persebahan kepada Ida Sang Hyang Widhi Wasa, sehingga sarana yang telah dibuat tidak sia-sia.

\section{SIMPULAN DAN SARAN}

Pelaksanaan pelatihan Upakara merupakan tahap awal untuk melestarikan Budaya Hindu yang secara tidak langsung akan membentuk karakter keperibadian umat yang memiliki sradha dan bhakti yang kuat dengan dasar pemahaman nilai-nilai ajaran agama Hindu yang akan menjadi faktor penentu kelangsungan tradisi budaya Hindu yang merupakan warisan adiluhung nenek moyang oleh karena itu optimalisasi dalam kegiatan pelatihan upakara sangatlah diperlukan dan harusnya terlaksana secara berkesinambungan dan sistematis. Partisipasi dan komitmen peserta pelatihan upakara untuk mengikuti kegiatan dapat menentukan lancar atau tidaknya suatu proses pelatihan baik dari segi penerimaan materi ataupun praktek, yang dimana pelatihan ini merupakan sebagai bentuk implementasi penyaluran keilmuan dan keterampilan pada masyarakat Hindu. Secara umum dapat digambarkan bahwa kegiatan pelatihan sarana upakara pabersihan yang diselenggarakan oleh Pinandita Sanggraha Nusantara Koordinator Wilayah Nusa Tenggara Barat ini sudah berjalan dengan baik, Peserta Pelatihan sudah mampu mengikuti proses pembelajaran secara antusias dan nyaman mengikuti proses pembelajaran penyampaian materi dari narasumber yang ditunjukan dengan antusias memberikan feedback sehingga terjadi interaksi tanya jawab dalam penyampaian materi begitu pula pada kegiatan praktek para peserta yang dibagi menjadi tujuh kelompok dengan keseluruhan diberikan tugas membuat sarana upakara sesuai urutan undian yang telah diambil menyelesaikan seluruh tugas dengan baik, benar dan lengkap sehingga sarana yang telah dibuat masingmasing kelompok dapat digunakan sebagai sarana upakara dalam kegiatan upacara pabersihan.

Namun karena kondisi pandemi covid-19 maka kegiatan tidak dapat secara maksimal menyerap peserta karena jumlah peserta dibatasi hanya untuk 50 orang dan kegiatan upacara penutupan dilaksanakan secara Daring/virtual mengingat situasi dan kondisi yang tidak memungkinkan karena pembatasan kegiatan yang menimbulkan kerumunan warga. Kedepan diharapkan pelatihan pembuatan sarana upakara dalam rangka pengabdian kepada masyarakat Ini hendaknya dapat lebih optimal dan berkesinambungan, selain itu diharapkan agar materi yang telah diperoleh dapat teraplikasi dalam kehidupan sehari-hari baik dilingkungan keluarga maupun masyarakat. 


\section{UCAPAN TERIMAKASIH}

Pada kesempatan ini kami mengucapkan terima kasih kepada Ketua PHDI Provinsi Nusa Tenggara Barat, atas dukungan secara moril sehingga pelatihan ini dapat terlaksana sesuai dengan jadwal yang telah di tentukan, tidak lupa kami juga mengucapkan terimakasih kepada Kepala Bidang Bimas Hindu Kantor Kementerian Agama Provinsi Nusa Tenggara Barat yang telah memberikan motivasi atas terselenggaranya program Pelatihan Upakara Pabersihan ini. Dan tidak lupa pula kami sampaikan ucapan terimakasih yang sedalamdalamnya kepada seluruh Anggota PSN Kabupaten /Kota se-Nusa Tenggara Barat dan masyarakat Hindu yang telah berpartisipasi dalam kegiatan ini.

\section{DAFTAR RUJUKAN}

Arwati, Made Sri. 2003. Byakala, Tebasan Durmenggala.

Ardika Yasa, I. M. (2020). Nilai-Nilai Pendidikan Dalam Budaya Tarung Presean Di Lombok Barat (Perspektif Agama Hindu). Jurnal Penelitian Agama Hindu. https://doi.org/10.25078/jpah.v4i1.1334

Ardika Yasa, I. M. (2020). Upacara Ngaturang Cicipan di Pura Jamintura Desa Banyu Urip (Perspektif Pendidikan Agama Hindu). Kamaya: Jurnal Ilmu Agama. https://doi.org/10.37329/kamaya.v3i2.4 35

Arta Jaya, K. (2019). Membangun Mutu Pendidikan Karakter Siswa Melalui Implementasi Ajaran Tri Hita Karana. Jurnal Penjaminan Mutu, 5(1), 57. https://doi.org/10.25078/jpm.v5i1.759

Asmoro, A. Y., Bachri, T. B., \& Detmuliati, A. (2020). Analisis Potensi Wisata Desa Dengan Kerangka 6A Studi Kasus Desa Ngajum, Malang. Media Wisata, 18(2), 231-250. https://doi.org/10.36275/mws

Bartin, T. (2018). PENDIDIKAN ORANG DEWASA SEBAGAI BASIS PENDIDIKAN NON FORMAL. Jurnal Teknodik.

https://doi.org/10.32550/teknodik.v10i1 9.398

Gunada, I. W. A. (2020). Ajaran Agama Hindu Dalam Geguritan Candrabherawa Sebagai Penguatan Pendidikan Karakter. Kamaya : Jurnal Ilmu Agama, 3(2), $\quad$ 102-119. https://doi.org/10.37329/kamaya.v3i2.4 34

Gunada, I. W. A., \& Pramana, I. B. K. Y. (2021). Desain Pelatihan Menggambar Ornamen Bali Sebagai Implementasi Nilai Pendidikan Agama Hindu.
Jurdimas (Jurnal Pengabdian Kepada Masyarakat, 4(1), 77-84. https://doi.org/10.33330/jurdimas.v4i1. 909

Humanis, J., IImu, F., \& Unud, B. (2016). 3 [123]. $16,60-66$.

Made, N., Wisudariani, R., Ayu, I., Wirani, S., Putu, L., Adnyani, S., \& Suarcaya, P. (2020). Pembuatan sarana upakara keagamaan berorientasi home industri bagi siswa sekolah dasar. 1287-1294.

Rai, N., \& Pitriani, V. (2020). Perspektif Filsafat Hindu (Siwa. 4, 45-57.

Rifandi, A. (2013). Mutu Pembelajaran Dan Kompetensi Lulusan Diploma lii Politeknik. Jurnal Cakrawala Pendidikan, 5(1), 1-16. https://doi.org/10.21831/cp.v5i1.1266

Sukiani, N. K. (2019). Fungsi \& Makna Banten Prayascita Di Kota Denpasar. KULTURISTIK: Jurnal Bahasa Dan Budaya, 3(1), 84. https://doi.org/10.22225/kulturistik.3.1. 953

Sunhaji, S. (1970). KONSEP PENDIDIKAN ORANG DEWASA. Jurnal Kependidikan. https://doi.org/10.24090/jk.v1i1.528

Susanthi, I. G. A. A. D. (2021). KENDALA DALAM BELAJAR BAHASA INGGRIS DAN CARA MENGATASINYA. Linguistic Community Service Journal.

Tim, 1992. Catur Yadnya. Pemda Tk 1 Bali

Tim Penyusun, 2007. Catur Yadnya. kanwil Bidang Bimas Hindu NTB

Wardhani, I G.A.K. dan Wihardit, K., 2007. Penelitian Tindakan Kelas. Jakarta: Penerbit Universitas Terbuka. 